\title{
THE SERUM LEVEL OF IMMUNOREACTIVE LH IN INTACT AND SPAYED ANDROGEN-STERILIZED RATS
}

\author{
ANANT P. LABHSETWAR \\ Pharmaceuticals Division, Imperial Chemical Industries Limited, \\ Alderley Park, Macclesfield, Cheshire
}

(Received 28th May 1970)

\begin{abstract}
Summary. The serum levels of $\mathrm{LH}$ were measured by radioimmunoassay in androgen-sterilized and normal cyclic rats, both in the presence and absence of ovaries. The serum of persistent-oestrous rats contained significantly more $\mathrm{LH}$ than that of normal rats on the day of oestrus, the raised level being comparable to that found in the adult male rat. The pituitary gland of the persistent-oestrus rat resembled that of the normal rat in its response to ovariectomy by increased secretion of LH.
\end{abstract}

It is believed that the hypothalamus of the newborn female rat is sexually undifferentiated. Neonatal administration of testosterone to female rats induces a pattern of differentiation of the hypothalamus which is similar to that found in the male (Harris, 1964). This 'masculinization' of the hypothalamus presumably results in an acyclic secretion of luteinizing hormone (LH) like that which occurs in the male but unlike that which occurs in the female rat, and probably results in the ovulatory failure described in such rats (Harris, 1964), although their ovaries show reduced sensitivity to threshold doses of LH (Labhsetwar, unpublished observations). At the present time, data on blood levels of LH are scanty. Barraclough (1968) found a significantly higher plasma level of $L H$ in the androgen-treated rat than in the normal rat in oestrus. Ovariectomy of normal rats induced a rise in plasma $\mathrm{LH}$ but the same procedure produced a fall in the androgen-treated rats. On the other hand, Schiavi (1969) could not confirm the elevated blood LH in the intact androgen-treated rats and bilateral ovariectomy in his experience was associated with increased plasma-LH levels in both groups. Using rats in which persistent oestrus had been induced by lesions in the brain, McGann \& Ramirez (1964) could not detect any increase in plasma LH following ovariectomy. A marked discordance between these results can be attributed to very low levels of plasma LH, which are usually below the sensitivity of the bioassay (Parlow, 1961) used in the studies quoted. A very sensitive and apparently specific radioimmunoassay method for LH which recently became available provided an opportunity to measure circulatory levels of this hormone in normal and androgen-treated rats both in the presence and absence of ovaries and to compare these with the serum LH levels in males. 
Persistent oestrus was induced in rats of Alderley Park Strain I, originally derived from the Wistar rats and maintained under controlled conditions of photoperiod (light from 06.00 to 20.00 hours) and temperature $\left(71^{\circ} \mathrm{F}\right)$, by injecting $100 \mu \mathrm{g} /$ day of testosterone propionate $(0.05 \mathrm{ml}$ oil, s.c.) on Days 3,4 and 5 after birth. Vaginal smears taken daily from 48th day of life until autopsy contained cornified epithelial cells. One group of such rats was killed with ether on the morning of the 63rd day when blood was collected from the posterior vena cava. Another group was bilaterally spayed and blood was collected 10 days after the operation. To provide control data, blood was obtained from rats with 4-day oestrous cycles on the morning ( 11.00 hours) and afternoon (16.00 hours) of oestrus and pro-oestrus. Similarly, a group was spayed on the day of metoestrus of the 4-day cycle and killed 10 days later. Sexually mature males ( 3 months old) were also killed. Each blood sample was centrifuged at $5^{\circ} \mathrm{C}$ and the sera were kept frozen at $-20^{\circ} \mathrm{C}$ until they were assayed.

Individual serum samples were subsequently assayed in duplicate for $\mathrm{LH}$ by the radioimmunoassay method (Niswender, Midgley, Monroe \& Reichert, 1968). The ovine pituitary LH (lot LER-1056/C2) was labelled with ${ }^{125} \mathrm{I}$ (Amersham, England) using chloramine- $T$ as an oxidizing agent (Hunter \& Greenwood, 1962). The inorganic iodine not bound to LH was removed by column chromatography using Bio Gel P-60 (Bio Rad Laboratories, Richmond, California). The antiserum to 'purified' ovine LH, shown to cross-react quantitatively with the rat LH, was used in an initial dilution of $1: 32,000$ as recommended by Niswender \& Midgley (personal communication). The antibody-bound LH was separated from unbound hormone by the addition of a second antibody-anti-rabbit $\gamma$-globulin raised in the donkey (Burroughs Wellcome Co., London). This antibody was used in a dilution of $1: 50$. After an appropriate interval, the tubes were centrifuged in the cold and the precipitate counted in a gamma counter. NIH-LH-s-14 served as the standard and all results were expressed as $\mathrm{ng} / \mathrm{ml}$ serum $\left(1 \mathrm{ng}=10^{-6} \mathrm{mg}\right.$ ). When serum samples were assayed at two dose levels, the dose-response line appeared parallel with that of the standard. Other specificity criteria have been described by Niswender et al. (1968). The method is at least 200 times more sensitive than the ovarian ascorbic acid depletion assay of Parlow (1961).

The results show that the serum from the testosterone-treated rats contained significantly more LH than that of the normal cyclic rats killed on the day of oestrus. The morning and afternoon samples showed no difference and were pooled (Text-fig. 1). The raised LH levels were, in fact, comparable to those found in adult males. This would indicate that 'masculinization' of the hypothalamus by neonatal exposure to androgens so alters the secretory pattern of LH that it resembles that in the male, which, in turn, would account for the ovulatory failure in such rats. In view of the fact that the pituitary-LH content of normal rats on the day of oestrus is comparable to that of the persistent oestrous rats (see Barraclough, 1968), the elevated serum-LH level in the androgen-sterilized rats observed here suggests that there is increased synthesis and secretion of $\mathrm{LH}$ in the androgen-sterilized rats (it is assumed that the renal clearance and metabolic disposal of $\mathrm{LH}$ remain unaffected by testosterone treatment). 
Removal of the ovaries resulted in a significant rise in the serum LH of normal rats 10 days later (Text-fig. 1), a time when the pituitary LH content is known to be elevated (McGann \& Ramirez, 1964; Parlow, 1964; Labhsetwar, 1969). The same procedure in the persistent-oestrus rats also evoked a rise in serum LH of a comparable magnitude, which contrasts with the results of Barraclough (1968) who found a decrease in the gonadotrophin level 20 days after ovariectomy using a bioassay. The present results, however, agree with those of Schiavi

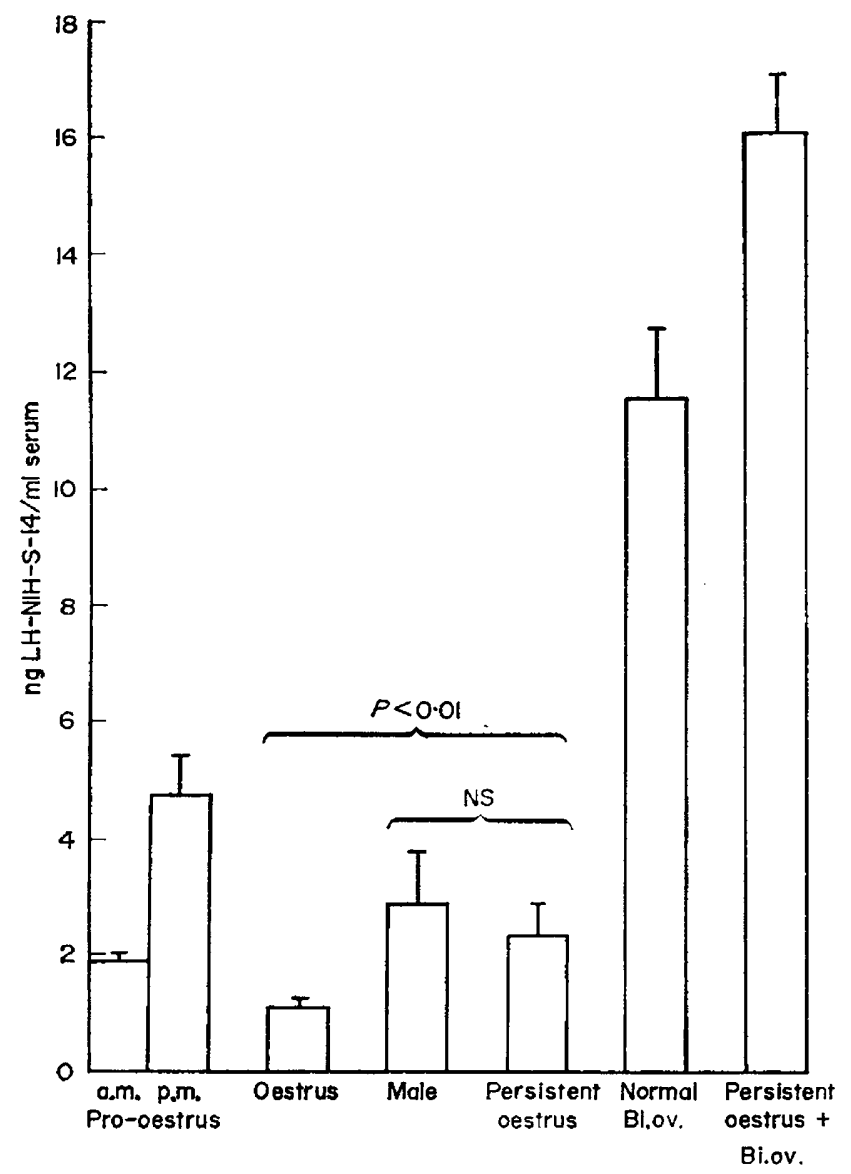

Text-FiG. 1. Serum levels of LH determined by radioimmunoassay in normal and persistent-oestrus rats which were either intact or bilaterally spayed (Bi. ov.). Each value represents mean \pm S.E. and is based on a duplicate assay of three to six serum samples/group (modal number 5). Noteworthy comparisons are as shown. Samples were obtained at 11.00 hours and at 16.00 hours.

(1969), who reported an increase within 2 months using the same assay. This suggests that the ovaries of persistent-oestrus rats, despite their lack of corpora lutea, are capable of exerting a negative feedback effect on the pituitaryhypothalamic complex. Ovariectomy eliminates this inhibitory effect, permitting hypersecretion of $\mathrm{LH}$ from the pituitary. 
The author records his appreciation to Mrs M. Redmond and Miss P. Maxwell for providing technical assistance and to the Endocrine Study Section, N.I.H., Bethesda, for reference standards. The radioimmunoassay for LH in this laboratory would not have been possible without the generous supplies of antigen and antibodies from Professor Midgley and Dr Niswender, University of Michigan, and Professor Reichert, Emory University. The author is greatly indebted to these workers for their assistance and also to Professor Harris and Dr Naftolin, University of Oxford, for providing access to their counting equipment.

\section{REFERENCES}

Barraclough, C. A. (1968) Alterations in reproductive function following prenatal and early postnatal exposure to hormones. Adv. reprod. Physiol. 3, 81.

HARRIs, G. W. (1964) Sex hormones, brain development and brain function. Endocrinology, 75, 627.

Hunter, W. M. \& Greenwood, F. G. (1962) Preparation of iodine-131 labelled human growth hormone of high specific activity. Nature, Lond. 194, 495.

Labhsetwar, A. P. (1969) Pituitary levels of FSH and LH at various intervals after ovariectomy in the rat. F. Reprod. Fert. 18, 531.

McCanN, S. M. \& RamiRez, V. D. (1964) The neuroendocrine regulation of hypophyseal luteinizing hormone secretion. Recent Prog. Horm. Res. 20, 131.

Niswender, G. D., Midgley, A. R., Jr, Monroe, S. E. \& Reichert, L. E., JR (1968) Radioimmunoassay for rat luteinizing hormone with antiovine $\mathrm{LH}$ serum and ovine $\mathrm{LH}^{{ }^{13}}{ }^{1} \mathrm{I}$. Proc. Soc. exp. Biol. Med. 128, 807.

PARLow, A. F. (1961) Bioassay of pituitary luteinizing hormone by depletion of ovarian ascorbic acid. In: Human Pituitary Gonadotropins, p. 300. Ed. A. Albert. Charles C. Thomas, Springfield.

PARLow, A. F. (1964) Comparison of pituitary and serum gonadotrophins of the rat. Endocrinology, 74, 489.

SCHIAVI, R. C. (1969) Effect of castration on pituitary and serum LH and FSH in testosterone-sterilized rats. Neuroendocrinology, 4, 101. 